\title{
Fish Assemblage Dynamics and Community Analysis in the Han River
}

\author{
Jun Kil Choi* \\ Department of Biological Science, Sangji University, Wonju 220-702, Korea
}

\begin{abstract}
A study of Han River fish assemblage dynamics for 4 years was conducted. From April 2005 to August, 2008, fishes inhabiting two sites of Han River were sampled for identification. For further analysis, 40 individuals of the dominant species were sampled monthly from March 2006 to November 2008. The fish assemblage at site 1 was dominated by Zacco platypus $(32.69 \%)$, while the subdominant species were Acheilognathus yamatsutae (14.4\%), Acanthorhodeus gracilis (9.43\%), Squalidus japonicus coreanus (6.84\%), and Tridentiger brevispinis (5.18\%). The most abundant species at site 2 was Korean Chub (Zacco koreanus) with relative abundance of $62.45 \%$ and followed by Pungtungia herzi (10.29\%), Coreoperca herzi (8.67\%), and Coreoleuciscus splendidus $(6.82 \%)$ as the subdominant species. At both sites, the endemics populations show an increasing pattern during the whole survey period, while the natives were declining in the last two years.
\end{abstract}

Keywords: fish assemblage, Han River, Fish Diversity, Pale Chub, Korean Chub

\section{INTRODUCTION}

Han River with the length of $470 \mathrm{~km}$, located in the geographic center of the Korean Peninsula, is a primary water resource for drinking, irrigation, navigation, and recreation to more than 23 million people. It has 35 tributaries with two major branches, the Namhan River and the Bukhan River (Ministry of Environment Republic of Korea, 2002).

Due to the rapid development in the economy and industries around the central part of Korea since 1960s, the water quality of the Han River gradually worsened (Ministry of Environment Republic of Korea, 2002). Although there has been some improvement as a result of a great investment in the management of the mainstream water quality since the late 1980s, there are still serious pollution problems (Kim et al., 2007). It means that continuous monitoring of Han River ecosystem health is urgent and important. Since the fish is known to be the best indicator of such purpose, regular monitoring effort should be carried out. Short term studies on fish diversity in Han River has been conducted by several researchers, but work for longer period in several years has not been presented.

\section{MATERIALS AND METHODS}

\section{Study area}

The locations of the sampling sites are presented in Fig.1.

\footnotetext{
*To whom correspondence should be addressed

Tel: 82-33-730-0434, Fax: 82-33-730-0430

E-mail: jkilchoi@sangji.ac.kr
}

\section{Site 1}

It is located in Sinjang-dong, Hanam-si, Gyeonggi-do, below Paldang Bridge with the coordinates of E $127^{\circ} 09^{\prime}$ $26^{\prime \prime} \mathrm{N} 37^{\circ} 34^{\prime} 05^{\prime \prime}$

\section{Site 2}

It is located in Deode-ri, Gapyeong-gun, Gyeonggi-do with the coordinates of E $37^{\circ} 56^{\prime} 48^{\prime \prime} \mathrm{S} 127^{\circ} 28^{\prime} 59^{\prime \prime}$

\section{Sampling and identification}

All fishes inhabit both sites were sampled twice a year for identification from 2005 until 2008. A further analysis was conducted to the dominant species based on the annual data. Forty individuals of Zacco platypus and Zacco koreanus were sampled monthly from March 2006 until November 2008, except for the freezing months.

Fish samples for community analysis were collected using throwing nets (mesh size $7 \times 7 \mathrm{~mm}$ ), hand nets (mesh size 4 $\times 4 \mathrm{~mm}$ ), and gill nets (mesh size $15 \times 15 \mathrm{~mm}$ ), while for dominant species analysis, the fish were collected using throwing nets (mesh size $7 \times 7 \mathrm{~mm}$ ). At the sampling sites, collected fish were directly fixed in $10 \%$ formalin solution and transported to the laboratory. Further process was done at the laboratory where the fish were identified using the methods described by Kim and Park (2002). The classification system followed Nelson (1994).

\section{Community analysis}

The dominance index were calculated using the Mc Naughton (1967)'s dominance index, while the Diversity index and 
Evenness index calculations were done using the ShannonWiener function (Pielou, 1966).

The condition factor was calculated based on analysis

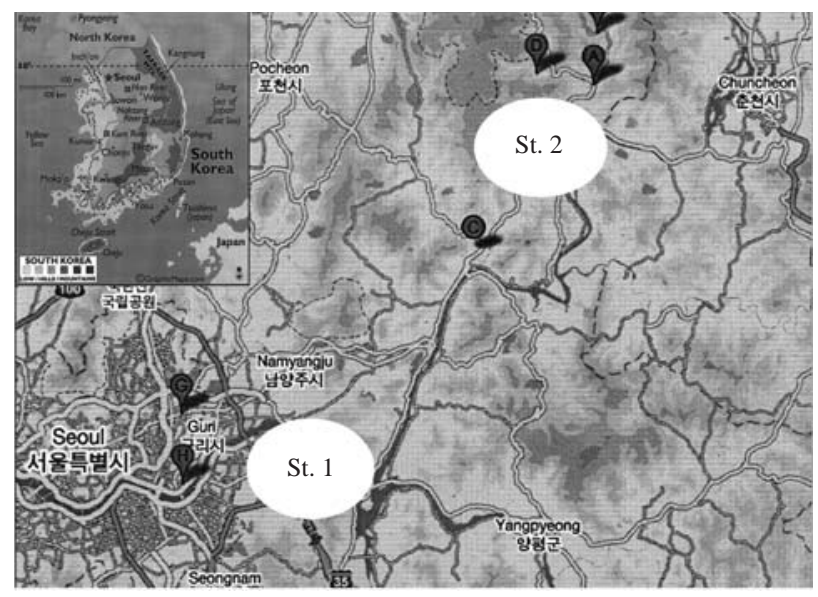

Fig. 1. Map of study area showing locations of the sites in Gyeonggi-do. described by Anderson and Neumann (1996): $\mathrm{K}=\mathrm{W} / \mathrm{L}^{3} \times$ $10^{5 \mathrm{w}}$ here $\mathrm{K}$ as the condition factor, $\mathrm{W}$ as the total weight and L as the total length. GSI was calculated as: GSI $(\%)=$ gonad weight/body weight $\times 100($ Strange, 1996).

\section{Statistical analysis}

The descriptive statistics, F test and Post-Hoc test of Oneway ANOVA was used to check any significant dissimilarity of the physico-chemical parameters.

Hierarchical Cluster Analysis was used for classifying the species variation found in both sites. To check the correlation among communityanalysis indices (Richness index, Diversity index, Dominance index, and Evenness index) with any of the physico-chemical parameters of the waters at each site, the Pearson's correlation test was used.

Linear Regression analysis was used to analyze the Lengthweight relationship and condition factor of the dominant species for each site, while Avedev means were used to determine the spawning period of the dominant species of each site.
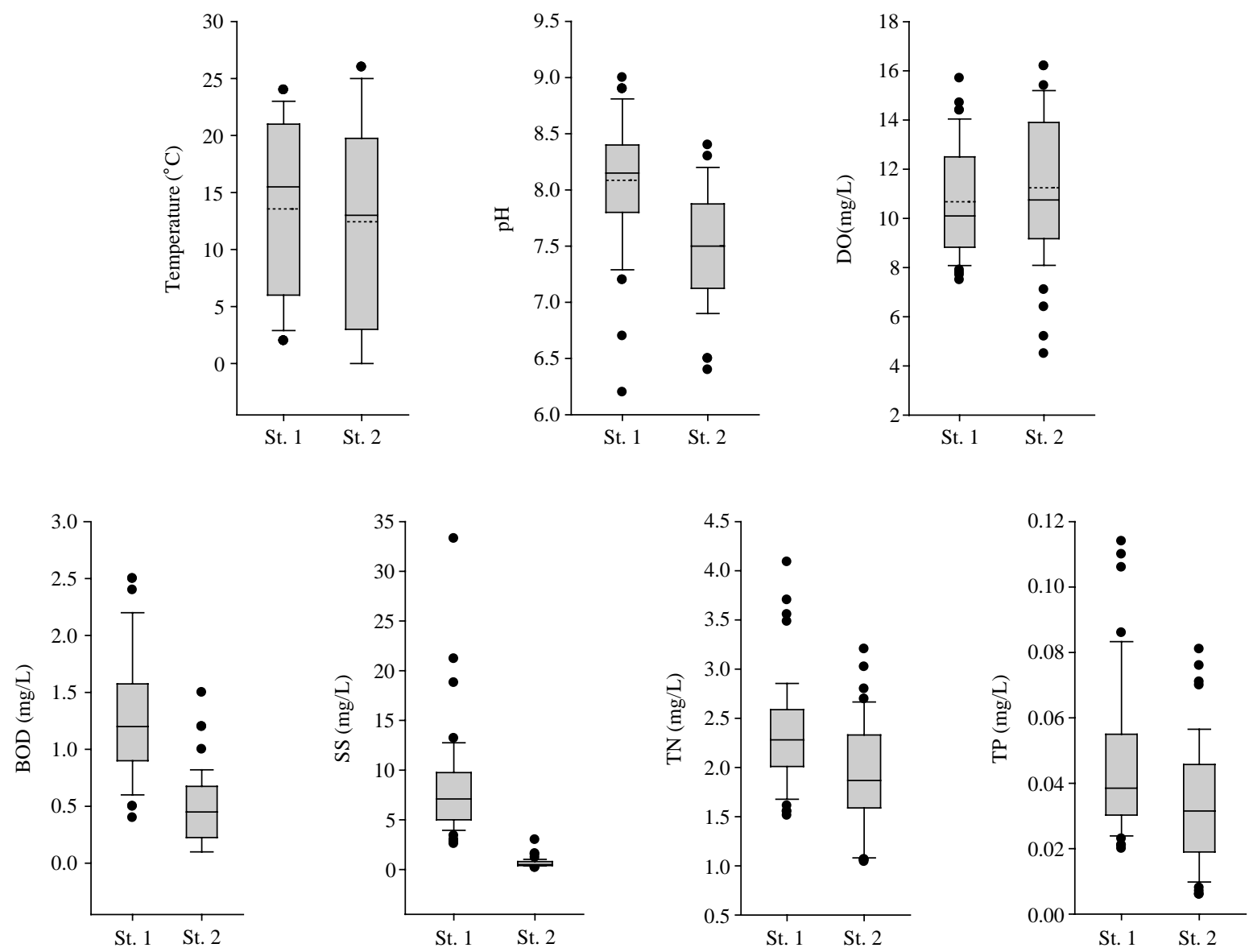

Fig. 2. Physico-chemical Analysis of each site from Jan 2005 to Dec 2008. 


\section{RESULTS AND DISCUSSION}

\section{Physico-chemical parameters}

The physico-chemical data presented in Fig. 2 shows that at Site 1, the range of temperature, $\mathrm{pH}, \mathrm{DO}, \mathrm{BOD}, \mathrm{SS}, \mathrm{TN}, \mathrm{TP}$ levels are 12.9-14, 7.8-8.4, 10.5-11, 1.1-1.4, 7.1-10.2, 1.92.7, and 0.04-0.05, respectively, while at Site 2, 11.7-12.8, 7.2-7.8, 10.3-11.9, 0.5-0.7, 0.5-0.9, 1.86-1.97 and 0.03-0.04. The One way ANOVA test result shows that the variation of temperature and DO for 4 years period at Site 2 was higher than at Site 1, while the variation of $\mathrm{pH}, \mathrm{BOD}, \mathrm{SS}, \mathrm{TN}$, and TP at Site 2 was lower than at Site 1 . The results also sug- gest that $\mathrm{pH}, \mathrm{BOD}, \mathrm{SS}, \mathrm{TN}$ and TP at Site 1 and Site 2 are significantly different $(\mathrm{P}<0.001)$ By comparing the means shown by descriptive statistics result, the levels of $\mathrm{pH}, \mathrm{BOD}$, $\mathrm{SS}, \mathrm{TN}$, and TP at Site 1 were significantly higher than at Site 2 . In addition, the $F$ value confirms that the highest difference between Site 1 and Site 2 was at the levels of BOD and SS (F value: 71.36, 96.93, also $\mathrm{P}$ values respectively).

According to EPA (1991), all the water quality parameters of both sites were within the range of healthy ecosystem standards, except for the TN level which was $>1 \mathrm{mg} / \mathrm{L}$.

The Site $1 \mathrm{~F}$ test result during survey period presents significant difference only at $\mathrm{pH}$ and $\mathrm{TN}$ levels (Sig. levels: 0.037; 0.008, respectively). However, the Post Hoc test

Table 1. Fish Assemblage and its Relative Abundance (Accumulated data of 2005-2008)

\begin{tabular}{|c|c|c|c|}
\hline \multicolumn{2}{|l|}{ St. 1} & \multicolumn{2}{|l|}{ St. 2} \\
\hline Species & $\mathrm{RA}(\%)$ & Species & RA (\%) \\
\hline Cyprinidae & 87.33 & Cyprinidae & 86.12 \\
\hline Cyprinus carpio@ & 0.65 & Pungtungia herzi ${ }^{\circ}$ & 10.29 \\
\hline Carassius auratus $^{\circ}$ & 2.16 & Pseudopungtungia tenuicorpa ${ }^{\# \star}$ & 4.34 \\
\hline Carassius cuvieri@ & 0.07 & Coreoleuciscus splendidus" & 6.82 \\
\hline Rhodeus uyekii" & 0.65 & Hemibarbus mylodon"** & 0.62 \\
\hline Rhodeus notatus ${ }^{\circ}$ & 3.02 & Gobiobotia brevibarba ${ }^{\star \star}$ & 0.62 \\
\hline Acheilognathus yamatsutae ${ }^{\#}$ & 14.4 & Microphysogobio longidorsalis"\# & 0.74 \\
\hline Acheilognathus rhombeus ${ }^{\circ}$ & 0.07 & Zacco koreanus ${ }^{\#}$ & 62.45 \\
\hline Acheilognathus gracilis ${ }^{\#}$ & 9.43 & Zacco platypus ${ }^{\circ}$ & 0.25 \\
\hline Pseudorasbora parva ${ }^{\circ}$ & 2.66 & Cobitidae & 2.48 \\
\hline Pungtungia herzi ${ }^{\circ}$ & 1.08 & Misgurnus anguillicaudatus ${ }^{\circ}$ & 0.12 \\
\hline Sarcocheilichthys variegatus wakiyae & 0.22 & Koreocobitis rotundicaudata\# & 2.11 \\
\hline Sarcocheilichthys nigripinnis morii ${ }^{\#}$ & 0.14 & ksookimia koreensis $\#$ & 0.25 \\
\hline Squalidus japonicus coreanus" & 6.84 & Silurus microdorsalis $\#$ & 0.50 \\
\hline Hemibarbus labeo ${ }^{\circ}$ & 4.46 & Amblycipitidae & 1.86 \\
\hline Hemibarbus longirostris ${ }^{\circ}$ & 0.5 & Liobagrus andersoni & 1.86 \\
\hline Pseudogobio esocinus ${ }^{\circ}$ & 2.59 & Centropomidae & 8.67 \\
\hline Abbottina rivulariso ${ }^{\circ}$ & 0.14 & Coreoperca herzi ${ }^{\#}$ & 8.67 \\
\hline Microphysogobio yaluensis ${ }^{\#}$ & 0.29 & Odontobutidae & 0.37 \\
\hline Microphysogobio jeoni ${ }^{\#}$ & 1.44 & Odontobutis platycephala\# & 0.37 \\
\hline Rhynchocypris oxycephalus ${ }^{\circ}$ & 0.5 & & \\
\hline Zacco platypus ${ }^{\circ}$ & 32.69 & & \\
\hline Opsariichthys uncirostris amurensis ${ }^{\circ}$ & 2.95 & & \\
\hline Hemiculter leucisculus ${ }^{\circ}$ & 0.07 & & \\
\hline Cobitidae & 0.14 & & \\
\hline Misgurnus anguillicaudatus ${ }^{\circ}$ & 0.07 & & \\
\hline Koreocobitis rotundicaudata" & 0.07 & & \\
\hline Centrarchidae & 0.14 & & \\
\hline Micropterus salmoides@ & 0.14 & & \\
\hline Odontobutidae & 0.65 & & \\
\hline Odontobutis interrupta ${ }^{\#}$ & 0.65 & & \\
\hline Gobiidae & 11.66 & & \\
\hline Chaenogobius urotaenius $^{\circ}$ & 0.29 & & \\
\hline Rhinogobius giurinus ${ }^{\circ}$ & 2.09 & & \\
\hline Rhinogobius brunneus ${ }^{\circ}$ & 4.1 & & \\
\hline Tridentiger brevispinis ${ }^{\circ}$ & 5.18 & & \\
\hline
\end{tabular}

\#: Endemics, ${ }^{\circ}$ : Natives, ${ }^{\circledR}$ : Introduced, RA: Relative Abundance 


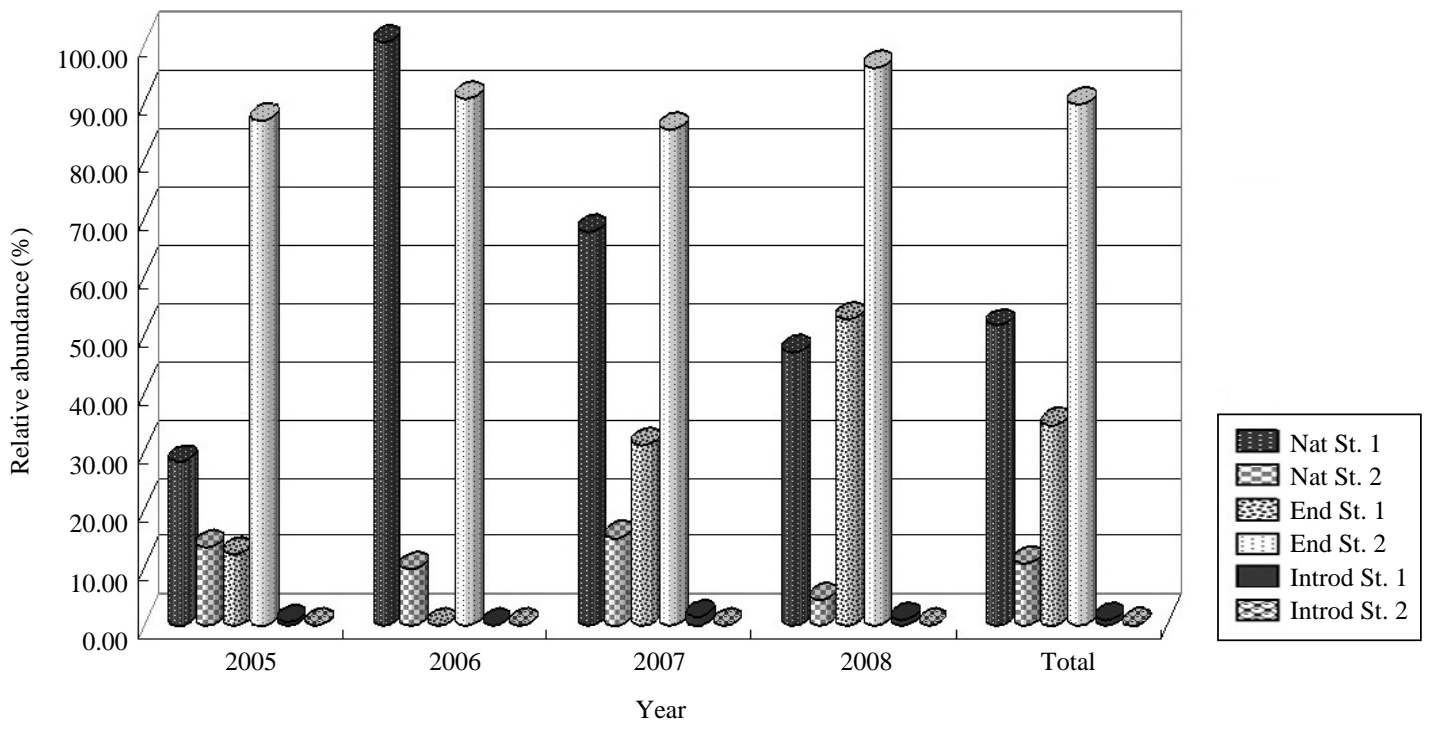

Fig. 3. RA of Native, Endemics, and Introduced Species at both sites during the surveys.

result for Site 1 only confirms that TN levels in 2008 were significantly lower compared to the TN levels in 2005 (Sig. level: 0.009) and the TN levels in 2007 (Sig. level: 0.023).

As for Site 2, the significant variations during 2005-2008 were at the level of $\mathrm{pH}$ and TP with $\mathrm{P}$ value of 0.013 and 0.041 , respectively. The Post Hoc test confirms difference for $\mathrm{pH}$ level between 2006 and 2008 (Sig. level of 0.01) with negative mean difference, while the difference for TP levels of 2007 and 2008 was significant (Sig. level of 0.013) with positive mean difference.

\section{The fish assemblage}

Of the 1389 total individuals, 33 species from 6 families were recorded during the survey period at Site 1. As shown in Table 1, the fish assemblage was dominated by Zacco platypus (32.69\%), while the subdominant species (with RA $>5 \%$ ) were Acheilognathus yamatsutae (14.4\%), Acanthorhodeus gracilis (9.43\%), Squalidus japonicus coreanus (6.84 $\%$ ), and Tridentiger brevispinis (5.18\%). The annual data also presents Pale Chub (Zacco platypus) as the most abundant species with relative abundance of $49.04 \%$ (2006), $55.29 \%$ (2007), and 32.89\% (2008), respectively. Although the 2008 data shows that the most abundant was Acheilognathus yamatsutae (23.3\%), Zacco platypus with relative abundance (RA) of $21.2 \%$ was also considered as the dominant species since the RA gap between them was too small. The results showing that Pale Chub (Zacco platypus) as the dominant species at Site 1 was expected since this species was also the most abundant species in most of large river systems of South
Korea (Jang et al., 2002b) and the subdominant at Mt. Jiri and Mt. Seorak National Parks (Jang et al., 2002a). This species was also included as an abundant species in Miho Stream (Son, 1983), Tamjin River (Hwang and Choi, 1995) and Hwangryong River System (Song and Park, 1994).

It is even considered as a representative species across the whole of East Asia (Chen, 1982; Shen et al., 1993).

From Site 2, 15 species from 6 families were recorded during 2005-2008 (Table 1). The most abundant species was Korean Chub (Zacco koreanus) with relative abundance of 62.45\% and followed by Pungtungia herzi (10.29\%), Coreoperca herzi (8.67\%), and Coreoleuciscus splendidus (6.82\%) as the subdominant species. The annual data during the surveys shows that Korean Chub was always present as the dominant species. This species was distinguished from the Dark Chub (Zacco temmincki) after 2005 by Kim et al. (2005).

Hemibarbus mylodon, one of the Natural Monuments, was surprisingly found at this area with a relative abundance of 0.62 in 2 years of survey (2005 and 2008). In addition, two endangered species (Pseudopungtungia tenuicorpa and Gobiobotia brevibarba) were also found at this site with relative abundance of 4.34 and 0.62 , respectively.

This founding was also previously reported by Jang et al. (2008) in the same tributary of Han River (North Han River). Coates et al. (2003) estimated that globally there are 155 , 154 , and 372 critically endangered, and vulnerable freshwater fish species, respectively. Therefore, the founding of these 3 species is important.

The fish assemblage distribution status (native, endemics, introduced) during the survey period for both sites is shown 
Dendrogram using average linkage (Between groups)

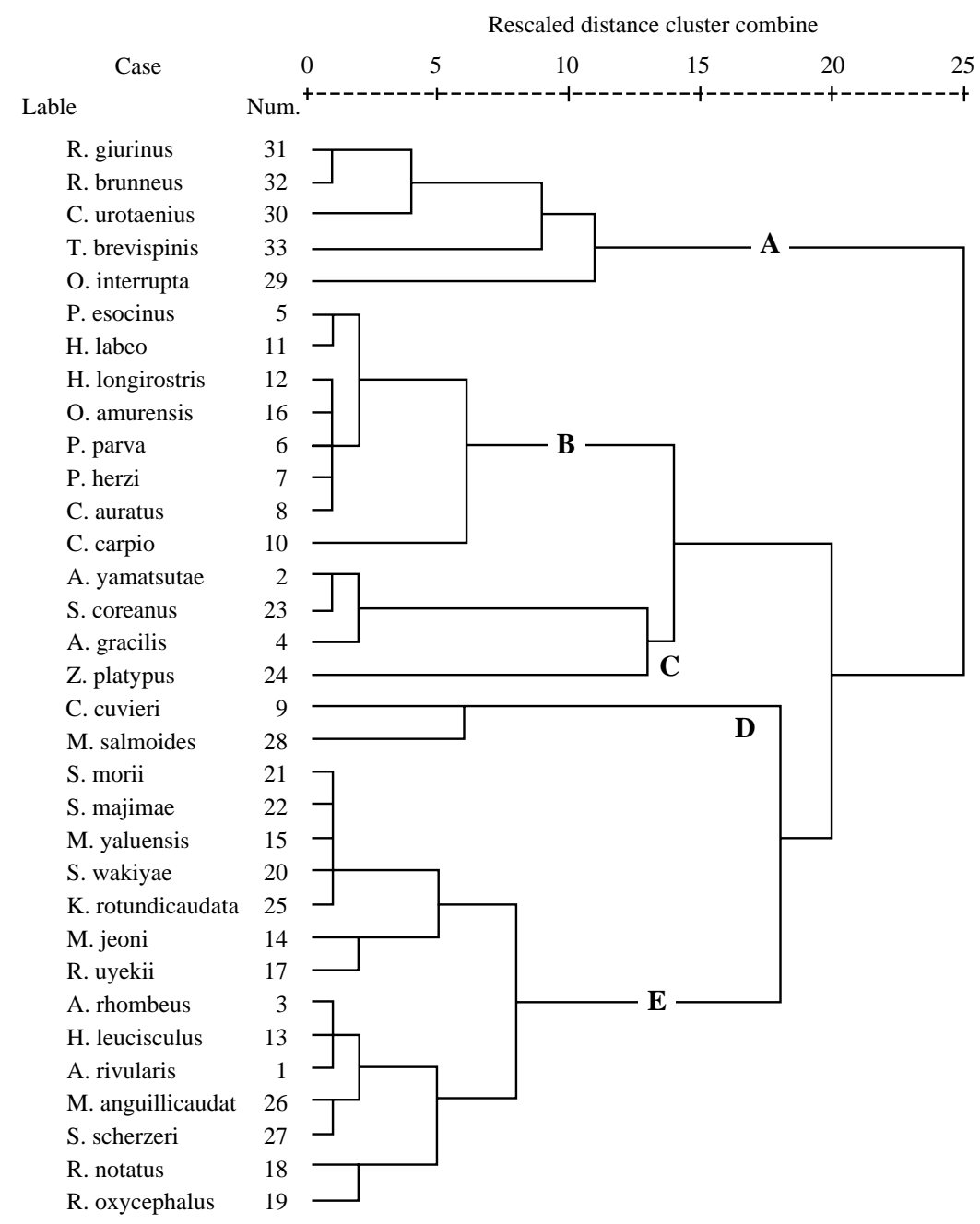

Fig. 4. Similarity Hierarchical Clustering of Fish assemblage at site 1 using Complete Linkage (between groups), based on the level of abundance, the presence frequency in years of survey, distribution status, and the family.

in Fig. 3. At Site 1, the graph shows that the native fish were the most abundant with RA of $51.42 \%$ while the endemics were the next abundant species (34.41\%). In contrast, the endemics (RA of $89.34 \%$ ) at Site 2 were strongly dominated the natives (RA of $10.66 \%$ ). At both sites, the endemics show an increasing pattern during the whole survey period, while the natives were declining in the last two years of survey.

The introduced species or the exotic species, each year contributed small number of relative abundance at Site 1 $(0.64 \%, 0 \%, 1.34 \%, 0.81 \%$, respectively) and none (RA of $0 \%$ ) at Site 2.

The highest abundance of native species was reported (Jang et al., 2002a, b) and confirmed at the present study. The endemic species (the second most abundant) in this study was also reported by De Silva et al. (2007) for South Korean water systems, as part of the total 49 endemic species in South Korea (Kim, 1995). According to Jang et al. (2003), the Korean endemic species of freshwater fish are mostly distributed in headwater/mountain streams. This statement is relevant to the current results showing that the abundance level of endemicity at the site located in mountain area was higher than the one located in the lower area.

Fig. 4 shows the hierarchical clustering for the fish assemblage based on the level of abundance, the presence frequency in years of survey, the fish distribution status and the family they belong to. The dendrogram identifies five major groups labeled as Group A, B, C, D, and E (Fig. 4). Group A represents the fish species which are natives/endemics, abundant/ less abundant/rare, present in two/three/four years of survey 
Dendrogram using average linkage (Between groups)

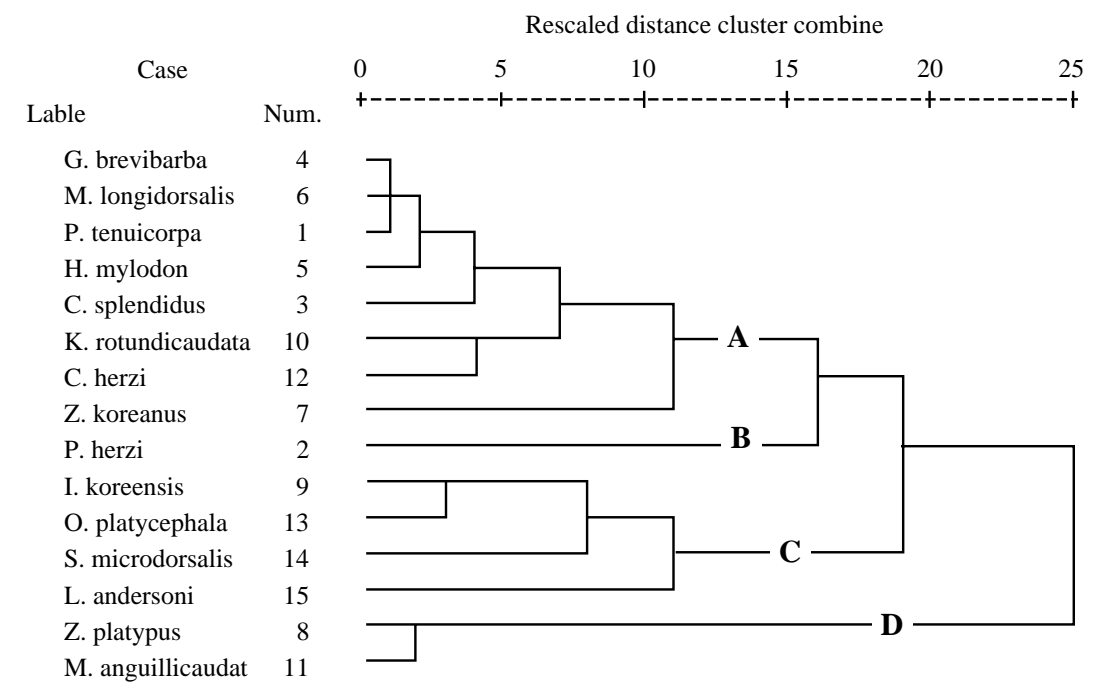

Fig. 5. Similarity Hierarchical Clustering of Fish assemblage at site 2 using Complete Linkage (between groups), based on the level of abundance, the presence frequency in years of survey, distribution status, and the family.

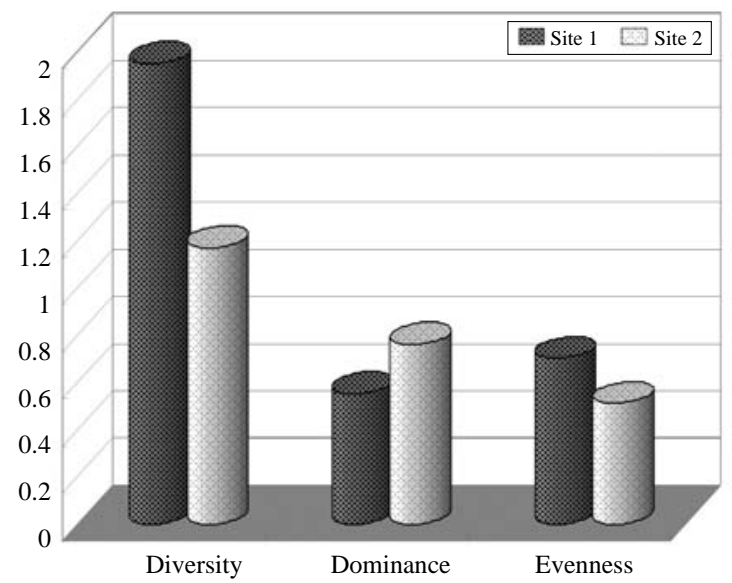

Fig. 6. Community Analysis Indices for each site during the years of survey (2005-2008).

and belong to Gobiidae family. Fish which are natives/exotic, less abundant, present in three/four years of survey, and belong to Cyprinidae are represented in Group B. Group C represents endemics/natives fish, most abundant/abundant, present in two/three/four years of survey, and belong to Cyprinidae. Group D represents exotic fish, rare, and only found in a year of survey, and belong to Cyprinidae/Centrarchidae, while endemic/native fish, rare/less abundant, present in one/two years of survey, and belong to either Cyprinidae/ Cobitidae/Centropomidae are represented in Group E.

At Site 2, the cluster presents 4 major groups labeled as Group A, B, C, and D (Fig. 5). Group A represents the fish
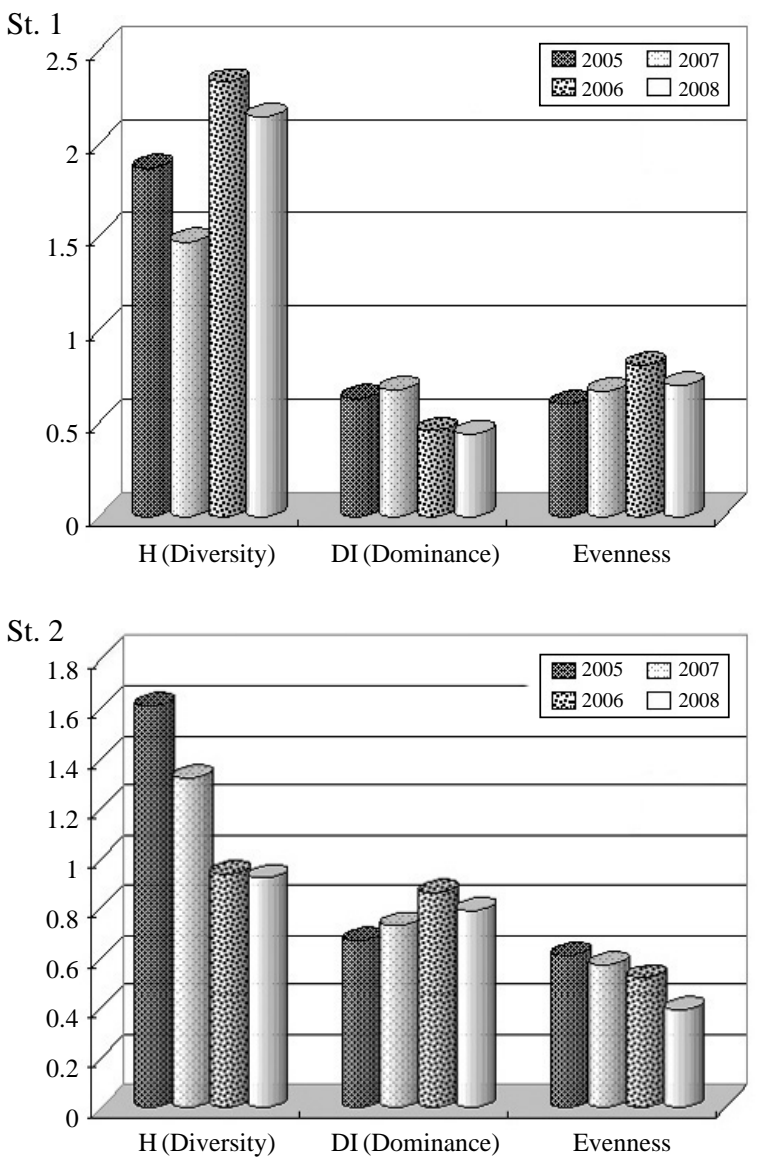

Fig. 7. Community Analysis Indices during the years of surveys (2005-2008). 
Table 2. Pearson Correlation test for per-survey Physico-chemical Parameters and Community Analysis Indices

\begin{tabular}{|c|c|c|c|c|c|c|c|c|c|}
\hline & & \multicolumn{2}{|c|}{ Richness } & \multicolumn{2}{|c|}{ Diversity } & \multicolumn{2}{|c|}{ Dominance } & \multicolumn{2}{|c|}{ Evenness } \\
\hline & & St. 1 & St. 2 & St. 1 & St. 2 & St. 1 & St. 2 & St. 1 & St. 2 \\
\hline \multirow{3}{*}{ TN } & Pearson Cor & 0.067 & $0.759 *$ & -0.414 & 0.463 & 0.588 & -0.379 & $-0.818^{*}$ & -0.107 \\
\hline & Sig. (2-tailed) & 0.876 & 0.029 & 0.308 & 0.248 & 0.125 & 0.354 & 0.013 & 0.801 \\
\hline & $\mathrm{N}$ & 8.000 & 8.000 & 8.000 & 8.000 & 8.000 & 8.000 & 8.000 & 8.000 \\
\hline \multirow{3}{*}{ TP } & Pearson Cor & 0.315 & - & -0.318 & - & 0.554 & - & $-0.869 * *$ & - \\
\hline & Sig. (2-tailed) & 0.448 & - & 0.443 & - & 0.154 & - & 0.005 & - \\
\hline & $\mathrm{N}$ & 8.000 & - & 8.000 & - & 8.000 & - & 8.000 & - \\
\hline
\end{tabular}

**Correlation is significant at the 0.01 level (2-tailed). *Correlation is significant at the 0.05 level (2-tailed).

species which are endemics, less abundant/abundant/most abundant, present in either two/three/four years of survey, and belong to Cyprinidae/Cobitidae/Centropomidae. Natives and abundant fish, present in all years of survey, and belong to Cyprinidae are represented in Group B. Group C represents endemic fish, rare/less abundant, present in either one/two/ three years of survey, and belong to Cobitidae/Odontobutidae/ Siluridae/Amblycipitidae. The last group (Group D) represents native fish, rarely found, present in one/two years of survey, and belong to Cyprinidae/Cobitidae.

\section{Community analysis}

The accumulative data of Community Analysis Indices for each site in 2005-2008 is presented in Fig. 6. Site 1 has much higher Diversity Index compared to Site $2(1.95,1.17$, respectively), while Site 2 shows a higher Dominance Index than Site $1(0.76,0.55$, respectively).

The changes of community indices from year of 2005 to 2008 are presented in Fig. 7 (Site 1 and 2). At Site 1, the diversity indices in 2005-2008 were 1.87, 1.47, 2.33, 2.14, respectively, indicating that in the last 2 years of survey (2007-2008) they were relatively increased. On the contrary, at Site 2 (Fig. 7) the diversity indices show a significant decreasing pattern (1.61, 1.32, 0.94, 0.92, respectively) while the dominance indices were slightly increased $(0.61,0.73,0.86,0.79$, respectively).

The Pearson Correlation test was conducted to check any correlation between the physico-chemical parameters and the community analysis indices. The results shown in Table 2 and 3 are only the ones with significant correlations.

At Site 1 (Table 2), the evenness index was significantly correlated to TN and TP(Sig. value of 0.013 and 0.005 , respectively). Both of the relationships show negative correlations, which mean the TN and TP levels in the water body were decreased along with the increasing Evenness indices. At Site 2 (Table 2), the results show a negative significant correlation between Richness indices and the levels of TN (with Sig. value of 0.029) which could indirectly affect the
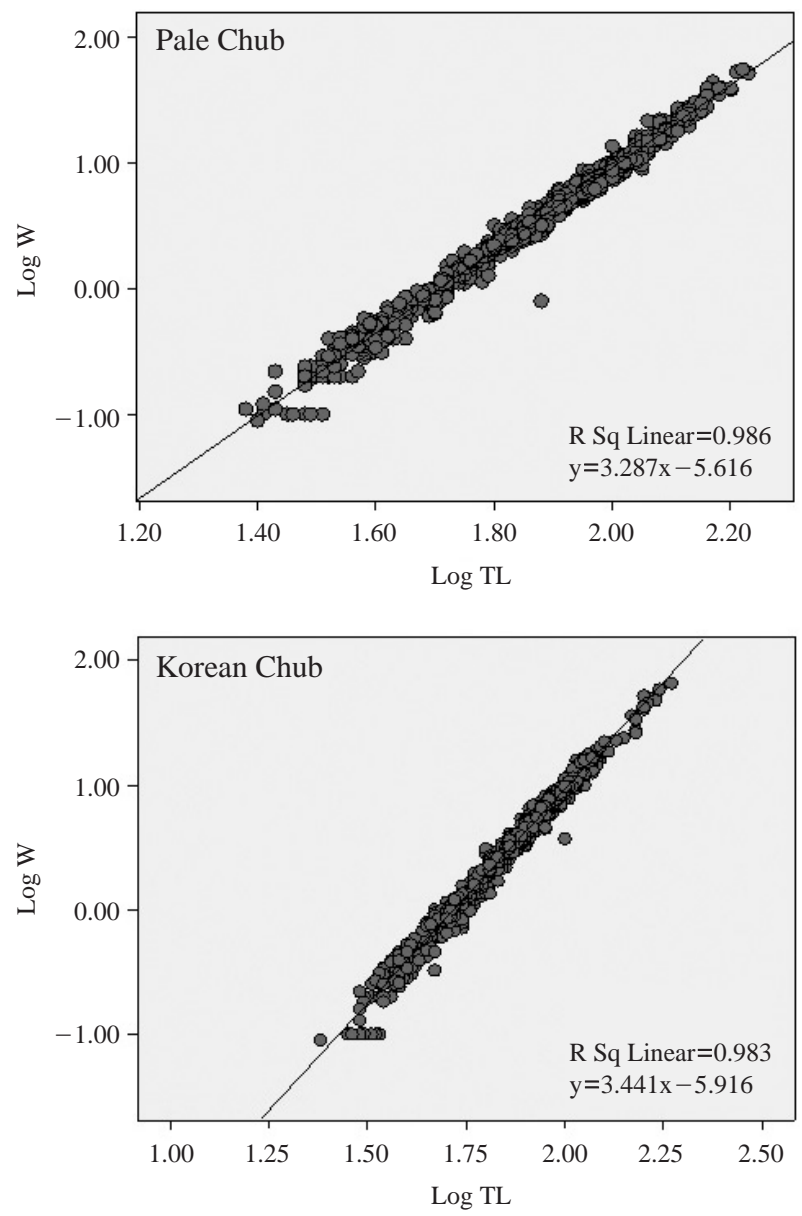

Fig. 8. Pale Chub LWR (log transformation) and Korean Chub LWR (log transformation) during the period of survey (2005-2008).

fish diversity.

The Physicochemical data shows signs of excessive TN levels which leading to eutrophication although the DO levels did not suggest this. The results showing that the annual mean of TP levels at Site 1 were all above $0.025 \mathrm{mg}$, also indicate that there was a tendency of eutrophication (Danilov 
Table 3. Linear Regression Statistics of LWR (Log Transformation) of Pale Chub And Korean Chub during the survey period

\begin{tabular}{|c|c|c|c|c|c|c|c|c|c|c|c|}
\hline \multicolumn{12}{|c|}{ Coefficients (a) } \\
\hline & & \multicolumn{4}{|c|}{$\begin{array}{l}\text { Unstandardized } \\
\text { coefficients }\end{array}$} & \multirow{2}{*}{\multicolumn{2}{|c|}{$\begin{array}{c}\begin{array}{c}\text { Standardized } \\
\text { coefficients }\end{array} \\
\text { Beta }\end{array}$}} & \multirow{2}{*}{\multicolumn{2}{|c|}{$\mathrm{t}$}} & \multirow{2}{*}{\multicolumn{2}{|c|}{ Sig. }} \\
\hline \multirow[t]{2}{*}{ Model } & & \multicolumn{2}{|c|}{ B } & \multicolumn{2}{|c|}{ Std. error } & & & & & & \\
\hline & & $\begin{array}{l}\text { Pale } \\
\text { Chub }\end{array}$ & $\begin{array}{c}\text { Korean } \\
\text { Chub }\end{array}$ & $\begin{array}{l}\text { Pale } \\
\text { Chub }\end{array}$ & $\begin{array}{c}\text { Korean } \\
\text { Chub }\end{array}$ & $\begin{array}{l}\text { Pale } \\
\text { Chub }\end{array}$ & $\begin{array}{c}\text { Korean } \\
\text { Chub }\end{array}$ & $\begin{array}{l}\text { Pale } \\
\text { Chub }\end{array}$ & $\begin{array}{c}\text { Korean } \\
\text { Chub }\end{array}$ & $\begin{array}{l}\text { Pale } \\
\text { Chub }\end{array}$ & $\begin{array}{c}\text { Korean } \\
\text { Chub }\end{array}$ \\
\hline 1 & (Constant) & -5.616 & -5.916 & 0.022 & 0.025 & & & -253.057 & -236.94 & .000 & .000 \\
\hline & $\log T L$ & 3.287 & 3.4417 & 0.012 & 0.014 & 0.993 & 0.992 & 271.468 & 251.421 & .000 & .000 \\
\hline
\end{tabular}

a. Dependent Variable: Log W
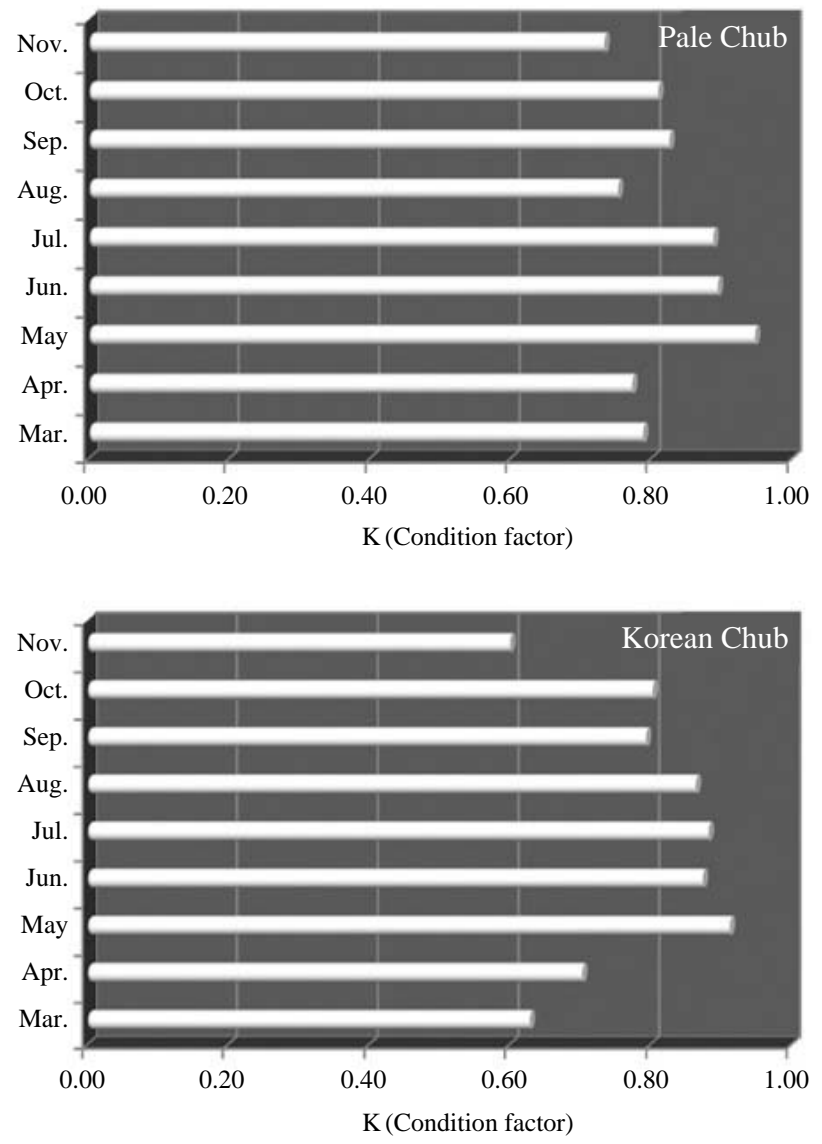

Fig. 9. Monthly Mean of Pale Chub and Korean Chub Condition Factor.

and Ekelund, 2000). Therefore, the declining of TP may have been the cause of the increasing evenness indices and given a contribution in the increase of fish diversity at the site.

It is possible that the uniformity in the distribution of individuals among species were increasing due to the decreasing of the exceeded nutrient levels. The significant negative correlation between the TN levels and richness indices could indirectly affect the fish diversity at Site 2 . However, there is not much information available explaining the response of fish communities in large rivers to the cascade of effects caused by an imbalance in nutrients and any indirect and probably unpredictable effect of enrichment (Miltner and Rankin, 1998).

\section{Dominant species population}

The Log-transformed Linear of the Pale Chub is presented in Fig. 8, which shows a positive allometric growth with regression coefficient $b$ of 3.287 and Correlation coefficient $r^{2}=0.986$. And as presented in Fig. 8, the Log-transformed Linear of the Korean Chub LWR also shows a positive allometric growth with regression coefficient $b$ of 3.441 and Correlation coefficient $r^{2}=0.983$. The statistical analysis for the Linear Regression of both species is presented in Table 3 showing the significance level ( $\mathrm{P}$ value) of $<0.001$.

A value significantly larger or smaller than 3.0 indicates allometric growth. A value less than 3.0 shows that that the fish becomes lighter (negative allometric) or greater than 3.0 indicates that the fish becomes heavier (positive allometric) for a particular length as it increases in size (Wooton, 1998). Wooton (1998)'s statements clearly suggest that within the Pale Chub and Korean Chub population collected in the present study, the allometric coefficients indicate both species have positive allometric growth.

Accumulated monthly data shows that the pale chub best condition was in May, June, and July which is in late spring to early summer (Fig. 9), while the Korean Chub best condition was in May to July (late spring to summer) (Fig. 9).

Monthly variations of the Pale Chub males and females Gonadosomatic Index (GSI) showed peaks in May to July which indicates the spawning season of this species at the particular site (Fig. 10). This result is similar with the founding by Nakamura (1952) which stated that Pale Chub spawning period occurs from May to June.

Fig. 10 presents the GSI Monthly variations of the Korean Chub both for males and females. The graph shows peaks in May and June indicating that the species spawns in this par- 

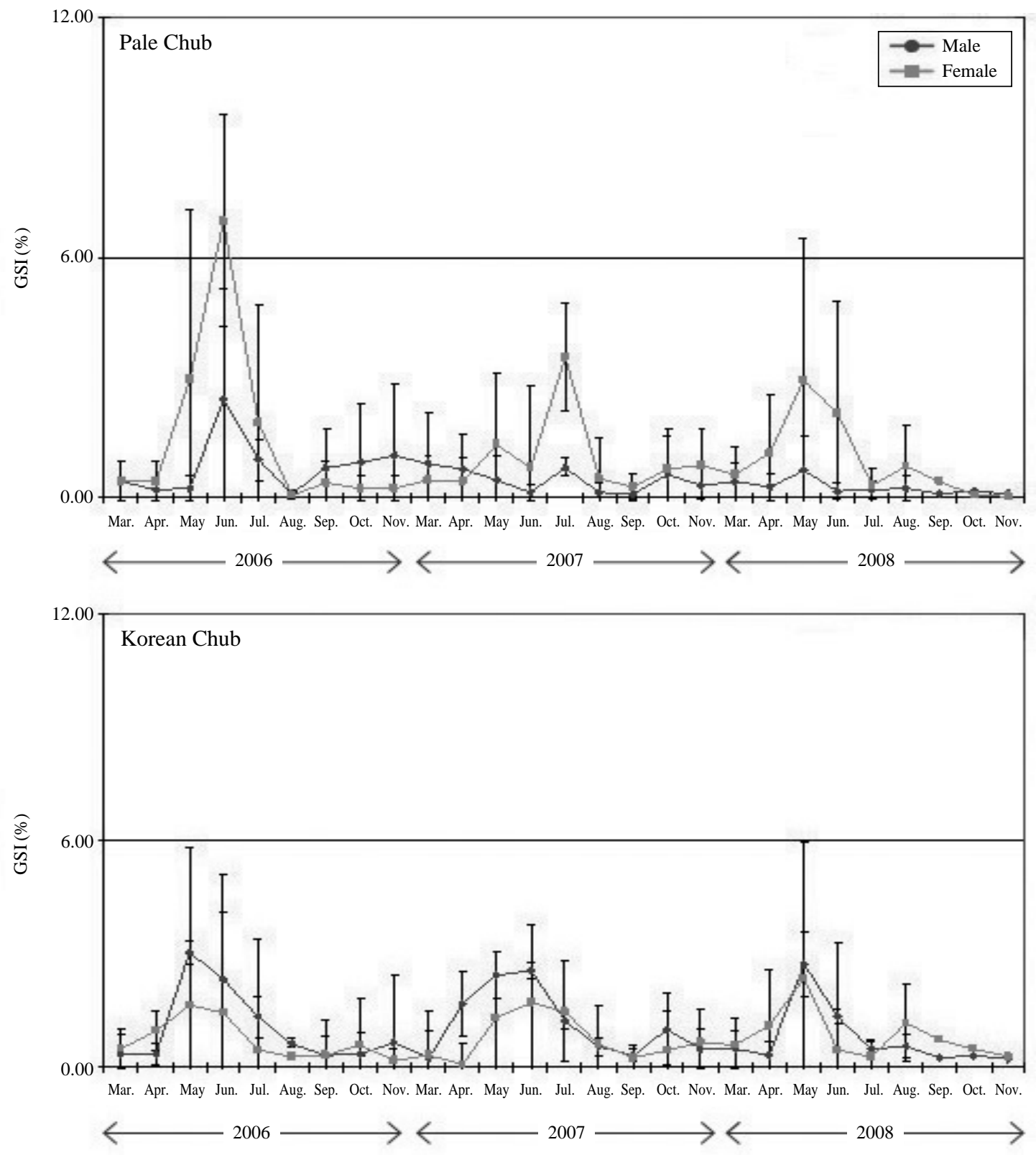

Fig. 10. Pale Chub GSI and Korean Chub GSI during the survey period.

ticular period. The importance of knowing about the spawning period was indicated by Schlosser (1990), which is an important component in determining basic life-history information, for assessing the impacts of environmental variability on the dynamics of fish populations.

\section{ACKNOWLEDGEMENTS}

This study was supported by the Ministry of Environment (Long-Term Ecological Research Program), Republic of
Korea.

\section{REFERENCES}

Anderson, R.O. and R.M. Neumann, 1996. Length, weight, and associated structural indices. In: Fisheries techniques, 2nd edn. (Eds., B.R. Murphy \& D.W Willis). pp. 447-482. American Fisheries Society, Bethesda, Maryland.

Cardinale, B., M. Palmer and S. Collins, 2002. Species diversity enhances ecosystem functioning through interspecific facili- 
tation. Nature, 415: 426-428.

Chen, Y., 1982. A revision of opsariichthine cyprinid fishes. Oceanol Limnol Sin., 13: 293-299.

Coates, D., O. Poeu, U. Suntornaratana, N.T. Tung and S. Viravong, 2003. Biodiversity and fisheries in the lower Mekong Basin. Mekong development series no. 2, Mekong River Commission, Phnom Pehn.

Danilov, R.A. and N.G.A. Ekelund, 2000. The use of epiphyton and epilithon data as a base for calculating ecological indices in monitoring of eutrophication in lakes in central sweeden. The Science of the Total Environment, 248: 63-70.

De Silva, S., W.A. Nigel and T.T.N. Thuy, 2007. Endemic Freshwater Finfish of Asia:distribution and conservation status. Diversity and Distributions (Diversity Distrib.), 13: 172-184.

Hwang, Y.J. and G.C. Choi, 1995. On the Ichtyofauna of Tamjin River System. Korean J. Ichtyology, 7(2): 135-139.

Jang, M.H., J.D. Yoon, J.H. Shin and G.J. Joo, 2008. Status of freshwater fish around the Korean Demilitarized Zone and its implications for conservation. Aquatic Conserv: Mar. Freshw. Ecosyst., 18: 819-828.

Jang, M.H., J.G. Kim, S.B. Park, K.S. Jeong, G.I. Cho and G.J. Joo, 2002b. The current status of the distribution of introduced fish in large river systems of South Korea. Internat. Rev. Hydrobiol., 87: 319-328.

Jang, M.H, M.C. Lucas and G.J. Joo, 2002a. The fish fauna of mountain streams in South Korean national parks and its significance to conservation of regional freshwater fish biodiversity. Biological Conservation, 114: 115-126.

Jang, M.H., M.C. Lucas and G.J. Joo, 2003. The fish fauna of mountain streams in South Korean national parks, and its significance to conservation of regional freshwater fish biodiversity. Biological Conservation, 114: 115-126.

Kim, I.S., 1995. The conservation and status of threatened fresh water fishes in Korea. In: Proceeding of Ichthyofauna and Characteristics of Freshwater Ecosystems in Korea (Eds., H.J. Lee and I.S. Kim). pp. 31-50. Ichthyology, Seoul, Korea.

Kim, I.S. and J.Y. Park, 2002. Freshwater Fish of Korea. KyoHak Publishing Co, Seoul, Korea.

Kim, I.S., M.K. Oh and K. Hosoya, 2005. A new species of Cyprinid Fish, Zacco koreanus with redescription of Z. temminckii (Cyprinidae) from Korea. Korean J. Ichtyology, 17(1): 1-7.
Kim, J.W., S.J. Ki, J. Moon, S.K. Yoo, A. Ryu, J. Won, H. Choi and J.H. Kim, 2007. Mass load-based pollution management of the Han River and its tributaries, Korea. Environmental Management, 41: 12-19.

McNaughton, S.J., 1967. Relationship among functional properties of California Glassland. Nature, 216: 168-144.

Miltner R.J. and E.T. Rankin, 1998. Primary nutrients and the biotic integrity of rivers and streams. Freshwater Biology, 40: 145-158.

Ministry of Environment Republic of Korea, 2002. Water environment of Seoul, in the status of the environment in the city of Seoul, Seoul, Korea.

Nakamura, K., 1952. Environment, food habit, spawning, development, growth and fishes of Zacco platypus in Chikuma River. Bull. Freshwater Fish. Lab., 1: 2-25 (in Japanese).

Nelson, J.S., 2007. Fishes of the World (4th ed.). John Wiley and sons. New York: 1-600.

Pielou E.C., 1966. The Measurement of diversity in different types of biological collections. Journal of Theoretical Biology, 13: 131-144.

Schlosser, I.J., 1990. In Brewer S.K., Fabeni C.F., Papolias D.M. 2007. Comparing histology and gonadosomatic index for determining spawning condition of small-bodied riverine Fishes. Ecology of Freshwater Fish 2008: 17: 54-58.

Shen, S.C., S.C. Lee, K.T. Shao, H.K. Mok, C.F. Chen and C.T. Chen, 1993. In Gwa Chin Ma, Katsutoshi Watanabe, HsienShao Tsao, and Hon-Tsen Yu. 2006. Ichtyol. Res., 53: 323329.

Son, Y.M., 1983. On the freshwater fish fauna in the Miho River. Korean J. Limnol. 16: 13-20.

Song, T.K. and K.Y. Park, 1994. The Freshwater Fish Fauna in Hwangryong River System. Bulletin of Institute of Littoral Environment Mokpo National Universitys, 11: 27-39.

Strange, R.J., 1996. Field examination of fishes. In: Fisheries techniques, 2nd edn. (Eds., B.R. Murphy and D.W. Willis). pp. 433-446. Bethesda, Maryland: American Fisheries Society.

Wootton, R.J., 1998. Ecology of Teleost Fishes. 2nd Ed. Dordrecht: Kulwer. 